\title{
ANGKA KEJADIAN DIABETES MELLITUS PADA LANSIA MIDDLE AGE DI MASA PANDEMI COVID-19
}

\section{The Prevalence Of Diabetes In Middle-Age Elderly During The COVID-19 Pandemic}

\section{Fahruddin Kurdi ${ }^{1 *}$, Zainal Abidin², Vespan Candra Surya ${ }^{3}$, Nabila Cindy Anggraeni ${ }^{3}$, Diwali Sukma Alyani ${ }^{3}$, Villyana Riskiyanti ${ }^{3}$}

1. Departemen Keperawatan Komunitas Fakultas Keperawatan Universitas Jember

2. Prodi DIII Keperawatan Kampus Lumajang Universitas Jember

3. Profesi Ners Fakultas Keperawatan Universitas Jember

\section{Riwayat artikel}

Diajukan: 7 Agustus 2021

Diterima: 6 September

2021

\section{Penulis Korespondensi:}

- Fahruddin Kurdi

- Fakultas Keperawatan

Universitas Jember

e-mail:

fahruddin.fkep@unej.ac.id

\section{Kata Kunci:}

Diabetes Mellitus; Lansia; COVID-19

\section{Abstrak}

Pendahuluan : Kelompok lanjut usia merupakan kelompok yang sangat beresiko mengalami morbiditas dan mortalitas akibat COVID-19 dengan berbagai komorbiditas salah satu diantaranya diabetes mellitus. Upaya promotif dan preventif kepada kelompok ini sangat perlu dilakukan di tingkat keluarga, masyarakat dan fasilitas kesehatan. Tujuan: Untuk mengetahui gambaran kejadian diabetes mellitus pada lanjut usia di masa pandemi COVID-19 di wilayah kerja Puskesmas Pakusari Kabupaten Jember pada tahun 2020. Metode: Penelitian ini merupakan penelitian kuantitatif deskriptif retrospektif melalui observasi data sekunder lansia selama tahun 2020 dengan jumlah 523 lansia yang diambil dari database Puskesmas Pakusari Kabupaten Jember melalui koordinasi dengan penanggung jawab kesehatan lanjut usia. Hasil: Penelitian menunjukkan distribusi data karakteristik lanjut usia dan diketahui bahwa kejadian penyakit diabetes mellitus banyak terjadi pada rentang usia 45-59 tahun atau pralansia yakni sebanyak 357 (68\%). Sebagian besar lanjut usia yang mengalami diabetes mellitus berjenis kelamin perempuan dengan jumlah 281 (54\%). Kesimpulan: Puskesmas Pakusari Kabupaten Jember dapat menjangkau para lansia dengan diabetes mellitus melalui telepon atau layanan kesehatan jarak jauh, menyiapkan persediaan obat dan persediaan kritis minimal 2 minggu di rumah, edukasi kepada lansia terkait gaya hidup, kunjungan rumah secara berkala terutama untuk lansia yang tidak pernah menghadiri jadwal kontrol rutin.

\section{Abstract}

Background: The elderly are the group most at risk of experiencing morbidity and mortality due to COVID-19 disease with various comorbidities, one of which is diabetes mellitus. Prevention of transmission through promotive and preventive efforts to elderly groups is very important, at the family, community and health facility levels. Objective: The purpose of this study was to describe the incidence of diabetes mellitus in the elderly during the COVID-19 pandemic in the working area of Pakusari Public Health Center, Jember Regency in 2020. Method: The design of this research is a retrospective quantitative descriptive study by observing secondary data for the elderly during 2020, amount 523 elderly was obtanied form of a database the Pakusari Public Health Center, Jember Regency through coordination with the senior person in charge. Results: The results showed the distribution of data on the characteristics of the elderly and it was known that the incidence of diabetes mellitus occurred mostly in the age range 45-59 years or pre-elderly, namely 357 (68\%) and most of those who experienced diabetes mellitus were female with a total of 281 (54\%). Conclusion: : Pakusari Public Health Center can reach elderly people with diabetes mellitus by telephone or longdistance health services, prepare medicine supplies and critical supplies at least 2 weeks at home, lifestyle education, periodic home visits especially for elderly who never attended a routine control schedule.
} 


\section{PENDAHULUAN}

Indonesia merupakan negara dengan struktur Aging Population, dimana proyeksi proporsi lanjut usia saat ini sebesar 27,08 juta jiwa atau 9,99 \% (Kemenkes RI, 2020). Lanjut usia (lansia) merupakan seseorang dengan kriteria sudah mencapai usia 60 tahun ke atas dan mengalami proses penuaan yang berlangsung sepanjang hidup, tidak hanya di mulai dari suatu waktu tertentu, tetapi dimulai sejak permulaan kehidupan. Pada masa ini tubuh akan terjadi perubahan fungsi dan penurunan daya tahan tubuh. Tua bukanlah sebuah penyakit, namun proses alami dalam siklus kehidupan manusia (Kholifah, 2016). Menurut WHO (1999), lansia di bagi menjadi beberapa kriteria yaitu : usia lanjut (elderly) antara usia 60-74 tahun, usia tua (old) 75-90 tahun, dan usia sangat tua (very old) adalah usia > 90 tahun. Sedangkan menurut Depkes RI (2005) dijelaskan bahwa usia lanjut prasenilis yaitu antara usia 45-59 tahun, usia lanjut yaitu usia 60 tahun ke atas dan usia lanjut beresiko yatu usia 70 tahun ke atas atau usia 60 tahun ke atas dengan masalah kesehatan.

Kelompok lanjut usia merupakan kelompok yang beresiko atau rentan mengalami keparahan/morbiditas dan mortalitas akibat COVID-19. Mortalitas karena COVID-19 di Indonesia meningkat seiring dengan meningkatnya usia yaitu $8 \%$ pada usia $45-54$ tahun, $14 \%$ pada usia 55- 64 tahun dan $22 \%$ pada usia 65 tahun ke atas. Hal ini dikarenakan pasien lanjut usia memiliki berbagai komorbiditas salah satu diantaranya adalah diabetes mellitus dan merupakan permasalahan kesehatan terbesar kedua yaitu sebanyak $5,7 \%$ setelah Hipertensi yaitu sebanyak 63,5\% (Riskesdas, 2018). Sangat perlu upaya promotif dan preventif kepada kelompok lansia, baik di tingkat keluarga, masyarakat dan fasilitas kesehatan (Kemenkes RI, 2020).

Pencegahan penularan COVID-19 pada kelompok lanjut usia, perlu antisipasi dampak dari adanya kebijakan pembatasan sosial, seperti kesehatan mental dan kognitif, peningkatan lanjut usia dengan penyakit kronis dan komplikasinya, serta ketergantungan lansia karena hambatan akses layanan kesehatan. Oleh karena itu sebagai kelompok rentan tentu saja lansia sangat memerlukan dukungan keluarga maupun masyarakat agar kesehatan dan kualitas hidup lansia selama masa pandemi COVID-19 tetap terjaga secara optimal (Kemenkes RI, 2020).
World Health Organization (WHO) menyampaikan bahwa penemuan pertama kali coronavirus di Wuhan dengan novel coronavirus 2019 (2019-nCoV). Kasus positif COVID-19 di Indonesia pertama kali ditemukan pada tanggal 2 Maret 2020. Tanggal 15 April 2020 kasus konfirmasi ada di angka 4.839 orang, dimana resiko kematian sebesar 9,5\% (459 orang), pasien yang dilakukan perawatan sejumlah 3.954 orang, dan pasien sembuh 426 orang. Saat itu 34 provinsi dinyatakan sebagai zona yang terinfeksi COVID-19. Beberapa provinsi di Indonesia dengan jumlah kasus konfirmasi lebih dari 100 orang yaitu DKI Jakarta, Jawa Barat, Jawa Timur, Banten Jawa Tengah, dan Sulawesi Selatan. (Pradana, A. A., Casman, Nur'aini. 2020).

Pemutusan rantai penularan virus perlu dilakukan, baik secara individu maupun kelompok. Secara individu dengan menjaga kebersihan diri seperti mencuci tangan. Secara kelompok berarti menerapkan social distancing sebagai upaya menurunkan resiko penularan COVID-19. Kebijakan di Indonesia melalui Pembatasan Sosial Berskala Besar (PSBB) adalah bentuk upaya social distancing. Upaya ini sangat efektif terutama ditujukan pada penduduk atau populasi suatu wilayah yang diduga terinfeksi COVID-19 untuk mencegah kemungkinan penyebaran virus. Kebijakan PSBB mengatur pelaksanaan sekolah dan bekerja; ritual keagamaan; kegiatan di tempat umum; serta pembatasan kegiatan lainnya (Pradana, A. A., Casman, Nur'aini. 2020).

Diabetes mellitus (DM) merupakan penyakit metabolic yang ditandai adanyan hiperglikemia yang disebabkan oleh penurunan sekresi insulin, penurunan fungsi insulin, ataupun keduanya. Hiperglikemia merupakan salah satu tanda khas penyakit diabetes mellitus, meskipun juga mungkin di dapatkan pada beberapa keadaan lain. Resistensi insulin pada otot dan liver serta kegagalan sel beta pankreas merupakan patofisiologi kerusakan sentral diabetes mellitus tipe-2. Kegagalan sel beta pankreas terjadi secara dini dan lebih berat daripada perkiraan awal. Organ lain ikut berperan dalam terjadinya gangguan toleransi glukosa meliputi jaringan lemak dengan meningkatnya lipolisis, defisiensi incretin oleh gastrointestinal, hiperglukagonemia pada sel alfa pankreas, peningkatan absorbsi glukosa pada ginjal, dan resistensi insulin oleh otak. Dapat disimpulkan bahwa patogenesis diabetes mellitus tipe-2 dikarenakan delapan 
faktor: penurunan sekresi insulin, sekresi glucagon yang meningkat, penurunan efek inkretin, peningkatan produksi glukosa otot, peningkatan lipolysis, tidak berfungsinya sistem neurotransmitter dan peningkatan reabsorbsi glukosa di ginjal (Prasetyo, 2019).

Prediksi peningkatan prevalensi diabetes mellitus di Indonesia dari 8,4 juta di tahun 2000 menjadi 21,3 juta di tahun 2030 , dan secara progresif akan meningkat 2-3 kali lipat di tahun 2035. Menurut data International Diabetes Federation (IDF). Pada tahun 2015 terdapat 415 juta penderita diabetes mellitus di dunia dan Indonesia menempati peringkat ke-7 dengan jumlah penderita diabetes mellitus sebanyak 10 juta orang (Prasetyo, 2019).

Pasien COVID-19 dengan diabetes mellitus cenderung mendapatkan perawatan Intensif Care Unit (ICU) dan ventilasi mekanis invasif akibat memiliki respons inflamasi sangat berat (Roncon dkk., 2020). Selain itu, pasien COVID-19 dengan diabetes mellitus memiliki prognosis yang buruk sehingga harapan hidup pasien COVID-19 dengan diabetes mellitus lebih pendek daripada yang tidak memiliki diabetes mellitus (DM). Hal ini terjadi karena COVID-19 menyebabkan disfungsi paru-paru dan inflamasi yang berat. Port entry virus ini adalah glikoprotein permukaan khusus pada ACE2, yaitu "spike". ACE2 melimpah di sel alveolar tipe II paru-paru. Jika jumlah ACE2 pada pasien COVID-19 berlebih, tingkat keparahan penyakit yang diderita pasien juga meningkat, seperti dapat menyebabkan Acute Respiratory Distress Syndrome (ARDS), kerusakan hati, jantung, ginjal, sampai menyebabkan kematian (Singh dkk., 2020). Pasien COVID-19 dengan diabetes mellitus cenderung dua kali lipat lebih beresiko untuk menderita gejala COVID- 19 yang berat dan dua kali lipat lebih berisiko meninggal akibat gejala tersebut (Kumar dkk., 2020).

Perawat yang ada di komunitas merupakan pelayan masyarakat yang secara intens berinteraksi dengan masyarakat. Mereka memperoleh kepercayaan dari komunitas yang mereka layani. Peran sebagai health promotor dan health educator dalam merubah perilaku sehat kepada kelompok rentan yang sering diabaikan. Intervensi yang dilakukan oleh tenaga kesehatan terlihat lebih efektif dibandingkan alternatif lain. Petugas Kesehatan ini juga harus memperhatikan bentuk penanganan masalah kesehatan masyarakat minoritas dengan ekonomi rendah, terpinggirkan, dan risiko tinggi (Pradana, et al, 2020).

Penerapan pembatasan sosial pada masa pandemi COVID-19 dapat mempengaruhi status kesehatan kelompok rentan dalam aktifitas sehari-hari, tujuan penulisan artikel ini antara lain untuk menggambarkan kejadian diabetes mellitus pada kelompok rentan lansia dengan komorbid akibat social distancing di Indonesia khususnya wilayah kerja Puskesmas Pakusari Kabupaten Jember.

\section{METODE}

Penelitian ini menggunakan desain kuantitatif deskriptif bersifat retrospektif, dengan melakukan observasi terhadap data sekunder lanjut usia selama tahun 2020 yakni berupa database yang diambil dari Puskesmas Pakusari Kabupaten Jember melalui koordinasi dengan penanggung jawab lansia. Didapatkan 523 lansia diabetes mellitus pada data sekunder di masa pandemi COVID-19 tahun 2020. Seluruh data yang telah dikumpulkan kemudian dilakukan observasi dan diolah secara univariate untuk membuat gambaran pada setiap variabel. Hasil penelitian akan ditampilkan dan diuraikan dalam bentuk tabel, diagram batang dan narasi.

\section{HASIL}

Berdasarkan hasil pengolahan data diperoleh hasil terkait jumlah lanjut usia yang mengalami diabetes mellitus di Puskesmas Pakusari Kabupaten Jember pada tahun 2020 yakni sebagai berikut :

(Lihat Tabel 1) 
Tabel 1. Distribusi Lansia dengan diabetes mellitus Berdasarkan Kelompok Usia dan Jenis Kelamin tiap bulan di Puskesmas Pakusari Kabupaten Jember Tahun 2020 ( $n=523)$

\begin{tabular}{lccccccc}
\hline \multirow{2}{*}{ Bulan } & \multicolumn{2}{c}{$\mathbf{4 5 - 5 9}$ th } & \multicolumn{6}{c}{$\mathbf{6 0 - 6 9}$ th } & \multicolumn{2}{c}{$>$ 70 th } & Total \\
\cline { 2 - 7 } \multicolumn{1}{c}{ L } & $\mathbf{P}$ & $\mathbf{L}$ & $\mathbf{P}$ & $\mathbf{L}$ & $\mathbf{P}$ & \\
\hline Januari & 22 & 17 & 3 & 3 & 1 & 2 & 48 \\
Februari & 11 & 16 & 9 & 13 & 3 & 3 & 55 \\
Maret & 14 & 23 & 13 & 13 & 5 & 6 & 74 \\
April & 10 & 12 & 5 & 10 & 0 & 0 & 37 \\
Mei & 12 & 13 & 3 & 4 & 0 & 1 & 33 \\
Juni & 13 & 13 & 6 & 7 & 3 & 2 & 44 \\
Juli & 12 & 22 & 4 & 6 & 0 & 0 & 44 \\
Agustus & 10 & 9 & 5 & 2 & 1 & 0 & 27 \\
September & 19 & 18 & 4 & 2 & 0 & 0 & 43 \\
Oktober & 8 & 16 & 1 & 2 & 1 & 4 & 32 \\
November & 18 & 9 & 4 & 7 & 0 & 1 & 39 \\
Desember & 18 & 22 & 2 & 2 & 2 & 1 & 47 \\
\hline \multicolumn{1}{c}{ Total } & $\mathbf{1 6 7}$ & $\mathbf{1 9 0}$ & $\mathbf{5 9}$ & $\mathbf{7 1}$ & $\mathbf{1 6}$ & $\mathbf{2 0}$ & \multirow{2}{*}{$\mathbf{5 2 3}$} \\
\hline
\end{tabular}

Tabel 2. Distribusi Lansia dengan diabetes mellitus Berdasarkan Usia dan Jenis Kelamin di Puskesmas Pakusari Kabupaten Jember Tahun 2020 (n=523)

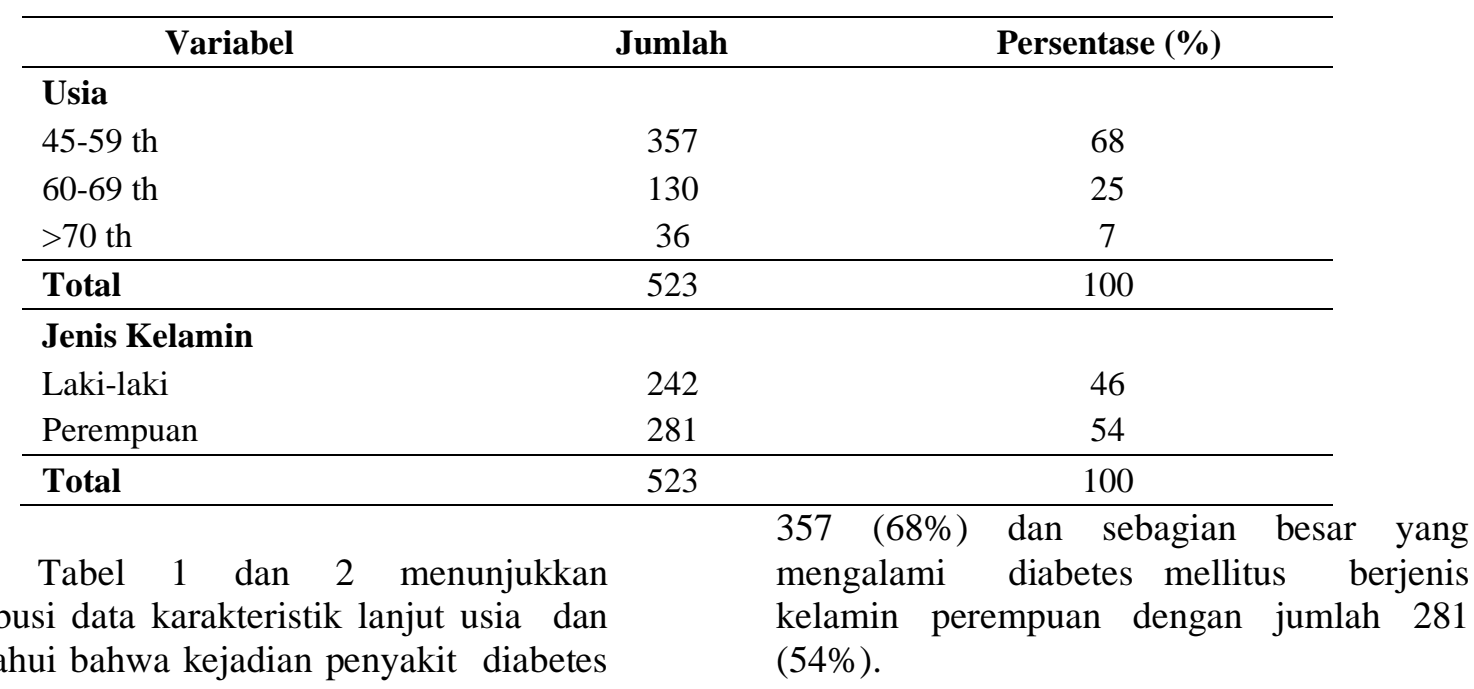

mellitus banyak terjadi pada rentang usia 45-59 tahun atau pra lansia yakni sebanyak 


\section{PEMBAHASAN}

Karakteristik lanjut usia yang mengalami diabetes mellitus lebih banyak terjadi pada perempuan dibandingkan pada laki-laki. Hasil ini sejalan dengan penelitian yang dilakukan oleh Kane dkk. (2018) yang menunjukkan bahwasanya jenis kelamin perempuan lebih beresiko mengalami Diabetes Melitus sejumlah 77 orang $(64,2 \%)$. Penelitian lain juga menunjukkan bahwa perempuan lebih banyak mengalami diabetes mellitus sejumlah 68 orang (50,4\%) (Halepian dkk., 2018). Penelitian lain juga menunjukkan bahwa perempuan lebih banyak mengalami diabetes mellitus tipe-2 berjumlah 227 orang $(52,4 \%)$ (Yavuz dkk., 2015).

Pada perempuan memiliki risiko tinggi terkena diabetes mellitus dikarenakan perempuan mempunyai Indeks Masa Tubuh (IMT) yang lebih besar, hal ini dikarenakan terjadinya penumpukan lemak tubuh dikarenakan adanya sindrom menopouse (Ramadhan, N dan Marissa, N. 2015). Terjadinya sindrom menopouse akan mempengaruhi perubahan hormon yang cukup signifikan. Hal tersebut secara tidak langsung akan meningkatkan Indeks Masa Tubuh (IMT) 5-10\%. Selain Indeks Masa Tubuh (IMT) yang lebih besar, perempuan juga lebih mudah mengalami stress, cemas dan depresi. Sedangkan stress dapat mempengaruhi kerja hormon kortisol, yang mana sekresi hormon kortisol dapat menganggu regulasi glukosa dalam darah (Winta dkk., 2018).

Hal di atas sangat mungkin terjadi, saat sistem kekebalan terganggu maka tubuh akan sulit untuk melawan virus dan kemungkinan mengarah ke masa pemulihan yang lebih lama. Virus dapat bereplikasi dengan cepat pada kondisi glukosa darah yang tinggi. Saat kondisi lansia terjadi penurunan maka dapat mengakibatkan keparahan ketika terinfeksi COVID-19 hingga kematian. Menjaga kesehatan lansia pada masa pandemi sangatlah penting, terutama bagi lansia yang memiliki penyakit diabetes, karena penyakit tersebut merupakan komorbid pada COVID-19.

Pada aspek usia, hasil penelitian menunjukkan kejadian diabetes mellitus lebih banyak terjadi pada lanjut usia pada rentang usia 46-59 tahun. Hasil penelitian lain yang dilakukan di Leicester UK juga menyebutkan bahwa rata-rata usia pasien yang mengalami diabetes mellitus tipe-2 yakni 53 tahun (Morrison dkk., 2019). Penelitian lain juga menunjukkan bahwa rata-rata usia pasien diabetes mellitus tipe-2 yakni 65,84 tahun (Halepian dkk., 2018). Usia diatas 30 tahun dapat terjadi perubahan anatomis, fisiologis serta biokimia pada tubuh seseorang, sehingga hal tersebut dapat menjadi salah satu faktor yang dapat berpengaruh akan terjadinya diabetes mellitus (DM). Pada usia diatas 30 tahun rata-rata akan mengalami kenaikan 6-13 $\mathrm{mg} / \mathrm{dL}$ kadar glukosa dalam darah setiap tahun, sehingga hal tersebut menjadikan usia berpengaruh dengan kejadian diabetes mellitus tipe-2 (Damayanti S, 2016). Usia diatas 40 tahun juga akan mengalami penurunan yang cepat pada fungsi fisiologis tubuh, sehingga hal ini dapat mempengaruhi kerja endokrin untuk menghasilkan insulin (Riyadi dan Sukarmin, 2008). Usia lebih dari 40 tahun memiliki risiko diabetes mellitus (DM), dimana pada umur tersebut akan terjadi peningkatan intoleransi glukosa, yang mana terjadinya proses penuaan akan menyebabkan berkurangnya produksi insulin oleh sel beta pankreas (Singal dkk., 2017).

Seiring dengan pertambahan usia maka mobilitas lansia juga berkurang. Hasil penelitian yang dilakukan Prastica, et. al, (2021) di UPT Pelayanan Sosial Tresna Werdha Bondowoso menunjukkan bahwa terdapat perubahan aktifitas fisik lansia selama masa pandemi, yang mana sebelum pandemi para lansia dengan leluasa beraktifitas bersama namun di masa pandemi segala aktifitas bersama dilakukan pembatasan. Selain itu pada lansia seringkali diikuti dengan penurunan sistem kekebalan tubuh. Hampir semua organ mengalami penurunan fungsi, bahkan diikuti menurunnya fungsi pelindung tubuh yang tidak bekerja sekuat seperti sediakala. Lansia ini termasuk kelompok rentan terhadap infeksi saluran pernafasan. Inilah alasan mengapa lansia sangat rentan terserang berbagai macam penyakit, termasuk paparan COVID-19. Imunitas dan fungsi tubuh yang telah melemah disertai dengan adanya komorbid dapat meningkatkan risiko COVID-19 pada lansia yang dapat menimbulkan gangguan dengan berbagai lever keparahan, bahkan kematian.

Menurut penanggung jawab lansia dan penanggung jawab Posbindu PTM di Puskemas Pakusari Kabupaten Jember, untuk lanjut usia dengan diabetes mellitus sendiri tidak dilakukan tindakan yang khusus kepada mereka. Kegiatan seperti Posbindu, Posyandu lansia, pengecekan tekanan darah, kunjungan 
rumah, senam lansia, pendidikan dan promosi kesehatan terkait dengan diet dan penyakit, penekanan pentingnya mengkonsumsi obat sesuai dengan jadwal dilakukan oleh petugas Puskesmas bersama dengan kader. Sementara untuk pemeriksaan gula darah dilakukan di Puskesmas pada saat kegiatan Prolanis yang dijadwalkan setiap bulan. Selain itu, kunjungan rumah juga dilakukan mahasiswa bersama dengan penanggung jawab lanjut usia dengan melakukan pengukuran tekanan darah, melakukan edukasi terkait penatalaksanaan diabetes mellitus yang meliputi pola makan, gaya hidup dan mengajarkan beberapa gerakan senam kaki diabetes mellitus.

Adapun kendala dalam pelaksanaan kegiatan bersama dengan lanjut usia yaitu, kurang aktifnya lanjut usia datang mengikuti kegiatan seperti Posbindu dan Posyandu lansia terutama saat masa pandemi COVID-19 tahun 2020. Dari data sekunder yang didapatkan diketahui bahwa kunjungan lanjut usia yang datang ke Posbindu juga mengalami penurunan selama masa pandemi karena adanya himbauan dari pemerintah untuk melakukan lock down dan mengurangi aktivitas diluar rumah. Adanya penurunan kunjungan lanjut usia ke Posbindu PTM menyebabkan data kejadian diabetes mellitus yang dialami oleh lanjut usia di Puskesmas Pakusari Kabupaten Jember tidak terpantau dan terdeteksi secara berkala. Kegiatan bulanan seperti Prolanis (Program pengendalian penyakit kronis) yang biasanya diadakan 3 bulan sekali juga mengalami kendala. Karena adanya pandemi COVID-19 mengakibatkan pelaksanaan kegiatan Prolanis tidak dapat dilakukan selama tahun 2020 karena himbauan pemerintah untuk meniadakan perkumpulan jumlah banyak orang dengan tujuan untuk menghindari dan memutus penyebaran virus COVID-19. Peserta Prolanis yang didominasi oleh lanjut usia juga merupakan orang yang berisiko tinggi terhadap penularan COVID-19.

\section{KESIMPULAN DAN SARAN}

Kejadian diabetes mellitus pada lanjut usia di masa pandemi COVID-19 di wilayah kerja Puskesmas Pakusari Kabupaten Jember pada tahun 2020 sebagian besar berjenis kelamin perempuan dengan jumlah 281 atau dengan presentase $54 \%$ dan mayoritas berada pada rentang usia 45-59 tahun dengan jumlah 357 dengan persentase $68 \%$.
Penyakit diabetes mellitus memiliki banyak dampak buruk bagi lanjut usia, oleh karena itu penting halnya untuk memantau dan menangani keluhan yang lebih banyak ditemukan pada lanjut usia dalam rentang usia 45-59 tahun dari pada rentang usia yang lainnya. Hal tersebut dapat diakibatkan karena kurangnya pemahaman dan kepatuhan lanjut usia terhadap gaya hidup sehat seperti pola makan, pola diet, aktivitas fisik dan cek gula darah yang dilakukan secara berkala. Dengan adanya masa pandemi COVID-19, monitoring dan perawatan kesehatan pada lanjut usia sebaiknya tetap harus dilaksanakan untuk mencegah bertambah parahnya gejala yang mungkin dikeluhkan oleh lanjut usia dengan diabetes mellitus. Pihak Puskesmas Pakusari Kabupaten Jember terutama penanggung jawab lansia dan petugas Posbindu PTM dapat menjangkau para lanjut usia dengan diabetes mellitus melalui telepon atau layanan kesehatan jarak jauh, menyarankan lanjut usia untuk menyiapkan persediaan obat dan persediaan kritis minimal 2 minggu di rumah, serta edukasi kepada lanjut usia terkait gaya hidup. Kegiatan Puskesmas kepada lanjut usia juga dapat dilakukan dengan kunjungan rumah secara berkala terutama untuk lanjut usia yang tidak pernah menghadiri jadwal kontrol rutin.

\section{DAFTAR PUSTAKA}

Damayanti S. 2016. Diabetes Melitus Dan Penatalaksanaan Keperawatan. Yogyakarta: Nuha Medika.

Halepian, L., M. B. Saleh, S. Hallit, dan L. R. Khabbaz. 2018. Adherence to insulin, emotional distress, and trust in physician among patients with diabetes: a crosssectional study. Diabetes Therapy. 9(2):713-726.

Kane, N. S., C. J. Hoogendoorn, M. L. Tanenbaum, dan J. S. Gonzalez. 2018. Physical symptom complaints, cognitive emotion regulation strategies, selfcompassion and diabetes distress among adults with type 2 diabetes. Diabetic Medicine. 35(12):1671-1677.

Kemenkes RI. 2020. Panduan Pelayanan Kesehatan Lanjut Usia Pada Era Pandemi Covid-19. Direktorat Jenderal Kesehatan Masyarakat. Jakarta: Kementrian Kesehatan RI. 
Kholifah, S. N. 2016. Keperawatan Gerontik. Kementrian Kesehatan Republik Indonesia. Cetakan pertama, Desember.

Kumar, A., Arora, A., Sharma, P., Anikhindi, S. A., Bansal, N., Singla, V., Khare, S., \& Srivastava, A. 2020. Is diabetes mellitus associated with mortality and severity of COVID-19/ A meta-analysis Diabetes \& Metabolic Syndrome: Clinical Research \& Reviews 14 (2020), 535-545.

https://doi.org/10.1016/j.dsx.2020.04.044

Morrison, A. E., F. Zaccardi, S. Chatterjee, E. Brady, Y. Doherty, N. Robertson, M. Hadjiconstantinou, L. Daniels, A. Hall, K. Khunti1, M. J. Davies, dan Affiliations. 2019. Self-compassion , metabolic control and health status in individuals with type 2 diabetes: a uk observational study. Clin Endocrinol Diabetes

Prasetyo, A. 2019. Tatalaksana diabetes mellitus Pada Pasien Geriatri. Pendidikan Dokter, Fakultas Kedokteran, Universitas Tanjungpura, Pontianak, Indonesia. CDK-277/vol. 46 no. 6.

Pradana, A. A., Casman, Nur'aini. 2020. Pengaruh Kebijakan Social DIstancing Pada Wabah Covid-19 Terhadap Kelompok Rentan Di Indonesia. Jurnal Kebijakan Kesehatan Indonesia : JKKI, Vol. 09, No. 02 Juni 2020.

Prastica, V.M., Susumaningrum, L.A., Rasni, H., Susanto, T., Kurdi, F., Qudsyiyah, R.F., Nasikhin K. 2021. Physical Activity and Sleep Quality of Elderly During The COVID-19 Pandemic Period. Media Keperawatan Indonesia. 4 (3): 191-200.

DOI

: 10.26714/mki.4.3.2021.191-200.

Ramadhan N dan Marissa N. 2015. Karakteristik penderita diabetes mellitus tipe 2 berdasarkan kadar hbalc di puskesmas jayabaru kota banda aceh. SEL. 2(2):49-56.

Riyadi, S. dan Sukarmin. 2008. Asuhan Keperawatan Pada Pasien Dengan Gangguan Eksokrin \& Endokrin Pada Pankreas. Yogyakarta: Graha Ilmu.
Roncon, L., Zuin, M., Rigatelli, G., \& Zuliani, G. 2020. Diabetic patient with COVID19 infection are at higher risk of ICU admission and poor short-term out come. Journal of Clinical Virology, 127(2020), 104354.

https://doi.org/10.1016/j.jcv.2020.104354

Singal, G., M. E. Katuuk, dan Y. B. Bataha. 2017. Hubungan pengetahuan tentang terapi insulin dengan inisiasi insulin pada pasien diabetes melitus tipe 2 di rumah sakit pancaran kasih gmim manado. Jurnal Keperawatan. 5(1)

Singh, A. K., Singh, A., Shaikh, A., Singh, R., \& Misra, A. 2020. Chloroquine and hydroxyclhoroquine in the treatment of COVID-19 with or without diabetes: A systematic search and a narrative review with a specia reference to India and other developing countries. Diabetes \& Metabolic Syndrome: Clinical Research \& Reviews 14 (2020), 241-246

Winta, A. E., E. Setiyorini, dan N. A. Wulandari. 2018. Hubungan kadar gula darah dengan tekanan darah pada lansia penderita diabetes tipe 2. Jurnal Ners Dan Kebidanan. 5(2):163-171.

Yavuz, D. G., S. Ozcan, dan O. Deyneli. 2015. Adherence to insulin treatment in insulinnaïve type 2 diabetic patients initiated on different insulin regimens. Patient Preference and Adherence. 9:1225-1231 